\title{
Entrepreneurship Development in Medicinal and Aromatic Plants: Prospects and Challenges
}

\author{
Rakesh Rathore* and Aditi Mathur
}

Institute of Agribusiness Management, SKRAU, Bikaner, Rajasthan (334 006), India

\section{Corresponding Author}

Rakesh Rathore

e-mail: rathorerakesh.iabm@gmail.com

\author{
Article History \\ Article ID: IJEP0219 \\ Received in $26^{\text {th }}$ October, 2017 \\ Received in revised form $3^{\text {rd }}$ February, 2018 \\ Accepted in final form $13^{\text {th }}$ February, 2018
}

\begin{abstract}
Entrepreneurship development in medicinal and aromatic plants is an approach of developing human resource and train the youth for taking risk and managing resources in efficient way. The objective of the study is to understand the current situation, trends and potential of medicinal and aromatic plants for development of entrepreneurship. Entrepreneurship in medicinal and aromatic plant includes production, processing, marketing, trade, and distribution of raw materials, also including supply of inputs and services. Medicinal and aromatic plants are demanded by herbal industries and pharmaceutical industry. The study will help in identifying entrepreneurship opportunities in medicinal and aromatic plants and challenges associated with it. The increasing demand of the pharmaceuticals industry have created problems of supply and one of the major difficulties being experienced by the industry is that of obtaining sufficient quantities of medicinal and aromatic plants for manufacturing good medicine. Technical guidance and consultancy provided to the farmers by the qualified entrepreneurs and establishing testing facilities and agri-clinics are some of the important areas of emerging opportunities in this sector. The study will also help in identifying the constraints that affect the spread of cultivation of medicinal and aromatic crops. The export market of herbal medicine of India is ₹ 700 Crores and only $40 \%$ is value addition and remaining $60 \%$ is of raw medicinal plants. The raw material is a very critical component for production and to meet the growing demand of private industry for extensive range of product. Therefore, to address this challenge for herbal products, the industries are ready to undertake adequate herbal cultivation.
\end{abstract}

Keywords: Aromatic plants, entrepreneurship, medicinal plants

\section{Introduction}

Medicinal and aromatic crops are the source of basic raw materials for pharmaceuticals, perfumery, flavor, soap and cosmetic industries. India is one of the major exports of crude drugs (Qureshi et al., 2011) mainly to six developed countries (USA, Germany, France, Switzerland, UK, and Japan about 75 to $80 \%$ of the total export of crude drugs from India. Emporium of the medicinal and aromatic plants and well established local healthcare tradition still relevant in indigenous healthcare system (Kapoor, 2012). As per estimates by National Medicinal Plants Board the annual growth in several herbs is between 15-30\% (Chaubey, 2011). Herbal product export can be accelerated with the setting up of export processing zones in about 12 states in India as their demand soars at a rate of over $25 \%$ (Assocham, 2008). Aloevera has been used for the manufacture of topical products such as ointments and gel preparations, as well as in the production of tablets and capsules (Karkala and Bidya, 2013). The excellent nutritive value and therapeutic value of the amla fruit offers an untapped potential for processing into several quality products. Hence, they are consumed mainly in the processed forms (Gudapaty et al., 2010).
Amla fruit is processed into murabbas, candy, dried chips, jelly, squash and syrup (Barwal et al., 2010). Amla is used in various ayurvedic preparations common among them are chyavanprash and triphala (Priyanka, 2014). India presents a great investment and business opportunity in the herbal sector, with the prospects of the country emerging as a global leader in the field (Mishra and Singh, 2013).

Figure 1 depicts that India is exporting $60 \%$ of crude drug out of total export (medicinal plants in raw form); $30 \%$ of semifinished products (semi-processed or partially processed products) and $10 \%$ of finished products (processed products). So, there is huge gap between raw products and processed products and thus, there are good opportunities for value addition and processing.

\subsection{Global market}

Global herbal market size is estimated approximately USD 72 billion and is expected to grow further at CAGR of $14.88 \%$ to reach USD 7 trillion by 2050. The main suppliers are China, Brazil and Indonesia. Europe is the largest herbal product market worth USD 7.5 billion. China is the major exporter of medicinal plants accounting to $15 \%$ of total medicinal 


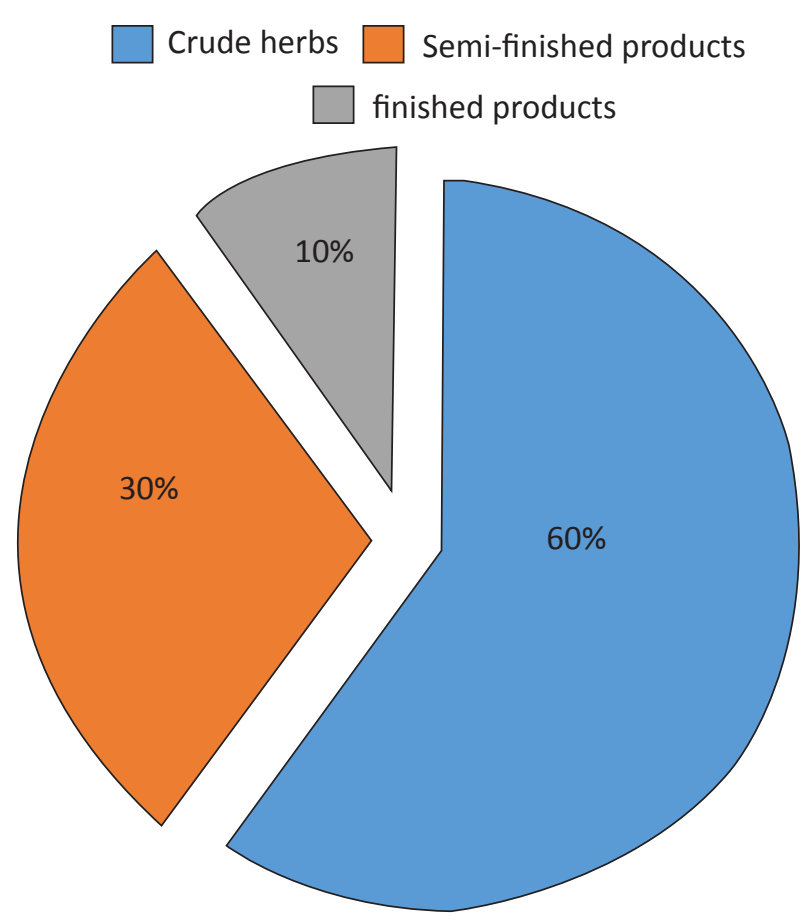

Figure 1: Percentage contribution in total export of MAP products from India

plant export globally. India ranks second globally in exports contributing $0.5 \%$ only. Demand for herbal raw drugs in the country has been growing at CAGR $4.8 \%$ since last 10 years and reached 5, 12,000 MT. The Current trend of medicinal plant based drug industry is to procure standard extract of plant as raw material. (Source: http://tejasisblog.blogspot.in/2017/ medicinal-plants-industry-2017.html).

\subsection{Marketing of medicinal and aromatic plants}

Many medicinal, cosmetic, Drug Company and food processing industry demanded medicinal and aromatic plants as a raw material for making various products including cosmetics, food and feed supplement and other herbal products. Companies also encourage nearby farmer to grow medicinal and aromatic plants with marketing agreement. Marketing channels of medicinal plants consist of collector, local regional small and big traders on basis of small and large market.

\section{Materials and Methods}

This study is based on secondary data. To meet the objectives of this study, data on different aspect such as area, production yield and market related information of medicinal and aromatic plants were collected from different secondary sources of information likewww.indiastat.com, various research paper, journals and magazine, books, newspaper, and from training given by Central Institutes of Medicinal and Aromatic Plants (Figure 2).

\section{Results and Discussion}

Sixteen medicinal plants were found to have high trade value
Medicinal and aromatic plant cultivator/collector Local collector at village level

Local trader (covering small trader)

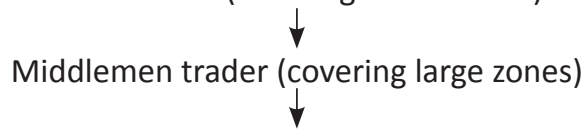

Wholesaler and regional traders based at regional market

Retailers and Industries /companies

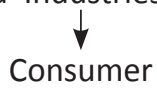

Figure 2: Market channels of medicinal plants

and high demand in both domestic as well as international market. Table 1 reveals that medicinal and aromatic plants are having so many uses and it is source of supply of raw material to the cosmetics, pharmaceuticals and food processing industry and there are huge opportunities in this sector for entrepreneurship development like consultancy service by qualified entrepreneur to the farmers and marketing, trading and processing of medicinal and aromatic plants (Table 2 and 3).

\subsection{Opportunities}

- Growing, selling and processing of medicinal and aromatic plants is good opportunities, processing and distillation unit is play important role for extraction of oil.

- Value addition is another opportunity. Value added products fetch higher price than raw products.

- Contract farming is another opportunity in this sector most of the company doing contract farming with farmers for obtaining good qualities of raw materials.

- In case of medicinal yam, company purchases dry yam at the rate of rupees one $\mathrm{kg}^{-1}$ having $1 \%$ diosgenin (medicinal component). If yam contains $3 \%$ diosgenin, then its rate is rupees three per $\mathrm{kg}^{-1}$.

- Processing of Isabgol husk and seed is another good opportunities as India is larger producer and exporter of Isabgol husk in the world (Figure 3).

\subsection{Institutes and government organization supports}

Several research institutes and government organizations

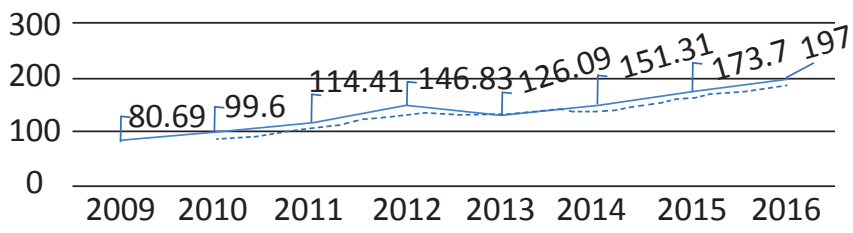

Source: https://www.connectindia.com/export-Isabgol+huskhs-code.html

Figure 3: Year wise export of Psyllium (Isabgol) husk from India value in US \$ billion 


\begin{tabular}{|c|c|c|c|}
\hline SI.No. & Common name & Scientific name & Uses \\
\hline 1. & Aloe vera & Aloe barbadensis & $\begin{array}{l}\text { Liquid aloe vera is used as drink, it is intestine regulator. Used in } \\
\text { lotion creams etc. }\end{array}$ \\
\hline 2. & Guggul & Commiphora wightii & $\begin{array}{l}\text { Resin is largely used as incense and fixative in perfumery and medi- } \\
\text { cine. }\end{array}$ \\
\hline 3. & Liquorice & Glycyrriza glabra & In modern medicine it is used in bronchial tablets and cough syrup. \\
\hline 4. & Medicinal yam & Dioscorea floribunda & $\begin{array}{l}\text { The steroids are used for the production of corticosteroids and } \\
\text { antifertility medicine. }\end{array}$ \\
\hline 5. & Safed Musli & Chlorophytum borivilianum & $\begin{array}{l}\text { Useful in diabetes and post gynaeconological problem, property of } \\
\text { rejuvenation of physical weakness }\end{array}$ \\
\hline 6. & Isabgol & Plantago ovata & Husk is used in antidiarrheal drugs. \\
\hline 7. & Ashwagandha & Withania somnifera & Seeds are diuretic in nature. \\
\hline 8. & Lemon grass & Cymbopogon flexuoses & Scenting soaps, perfumery and beverages. \\
\hline 9. & Chammomile & Matricaria chamimillae & Flavoring agent used in fine liquors, oil has antibacterial property. \\
\hline 10. & Patchouli & Pogostemon cablin & Oil used by the perfume industry, oil has fixative property. \\
\hline 11. & Tulsi & Ocimum basilicum & $\begin{array}{l}\text { Leaves used in flavoring foods and demanded by food processing } \\
\text { industry. }\end{array}$ \\
\hline 12. & Palmarosa & Cymbogon martinii & $\begin{array}{l}\text { Oil used in cosmetics and perfumery industry and it is source of very } \\
\text { high grade geraniol. }\end{array}$ \\
\hline
\end{tabular}

Source: (Srivastava, H.C. (2014) Medicinal and aromatic plants, Rameshwar Singh, ICAR, New Delhi)

Table 2: Medicinal and aromatic plants products for small and medium enterprise

\begin{tabular}{ll}
\hline Particular & Enterprise \\
\hline Seed & $\begin{array}{l}\text { Seed production and processing unit, } \\
\text { marketing of seeds, (seed companies) }\end{array}$ \\
Plant powder & $\begin{array}{l}\text { Plant powder processing industry as a } \\
\text { small or cottage industry. }\end{array}$ \\
Plant parts & $\begin{array}{l}\text { Marketing and export of medicinal } \\
\text { plant parts like roots, leaves, bark etc. }\end{array}$ \\
Herbal tea & $\begin{array}{l}\text { Worldwide demand of herbal tea is } \\
\text { increasing, packed in tea bag and sell- }\end{array}$ \\
ing herbal tea is good opportunities. & Making herbal juice like aonla, aloe \\
Herbal juice & vera juice is good opportunities. \\
Herbal extract & $\begin{array}{l}\text { Isolated minimum specific size compo- } \\
\text { nent demanded by cosmetic industry. }\end{array}$ \\
Herbal chocolate & $\begin{array}{l}\text { Sugar free chocolate and zero calorie } \\
\text { aerated soft drinks. }\end{array}$ \\
Herbal cosmetics & $\begin{array}{l}\text { Making cosmetic range product like } \\
\text { lotion, herbal cream etc. }\end{array}$
\end{tabular}

Source : (Rajeswara Rao et al. (2012) medicinal and aromatic plants products for small and medium enterprises)

like CSIR, NRCMAP, ICAR, NMPB and AYUSH are supporting medicinal plant sector by providing training, awareness and
Table 3: Area, production and productivity of aromatic plants in India

\begin{tabular}{lccc}
\hline Year & $\begin{array}{c}\text { Area (In ' 000 } \\
\text { Ha) }\end{array}$ & $\begin{array}{c}\text { Production } \\
\text { (In ' 000 MT) }\end{array}$ & $\begin{array}{c}\text { Productivity (In } \\
\text { MT ha-1 }^{-1}\end{array}$ \\
\hline $2007-08$ & 397 & 396 & 1.0 \\
$2008-09$ & 430 & 430 & 1.0 \\
$2010-11$ & 509 & 573 & 1.1 \\
$2011-12$ & 510 & 605 & 1.2 \\
$2012-13$ & 506 & 565 & 1.1 \\
$2013-14$ & 493 & 918 & 1.7 \\
$2014-15$ & 508 & 895 & 1.8 \\
$2015-16$ & 617 & 1165 & 1.9 \\
\hline
\end{tabular}

Source: (http://indiaagristat.com Ministry of Agriculture and Farmers Welfare, Govt. of India)

research and also developing different type of technology for cultivation, distillation, processing, marketing and entrepreneurship development. Besides, some financial and promotional agencies like NABARD, NHB and CAPART are providing direct and indirect financial support. HRDI (Herbal Research Development Institute) engaged in research and development activities and CHAMFI (Central Herbal Agro Marketing Federation of India) are providing marketing assistance to the farmers and also ensure better price of the produce. 


\subsection{Challenges}

- The increasing demand of medicinal plant based product have created problem of supply of raw materials and one the major difficulties being faced by the industries is that to obtaining sufficient quantities of raw materials of desired quality for the internal consumption as well as for export.

- The present pattern of production and trade of essential oils and aroma chemicals is characterized by factor such as fluctuation in demand and prices, competitive, instability in supplies with progressive increase in the numbers of products in many developing and industrialized countries.

- Large number of problem marketing of medicinal and aromatic plants is challenging task for farmer and that is reason many farmer are not interested for cultivation of medicinal and aromatic plants (Table 4).

\begin{tabular}{|c|c|c|c|c|}
\hline \multirow[t]{2}{*}{ Crops } & \multicolumn{2}{|c|}{$\begin{array}{c}\text { Economics of } \\
\text { cultivation }\end{array}$} & \multirow[t]{2}{*}{ Yield (ha) } & \multirow[t]{2}{*}{$\begin{array}{c}\text { Market rate } \\
\text { (₹) }\end{array}$} \\
\hline & $\begin{array}{l}\text { Expen- } \\
\text { diture }\end{array}$ & $\begin{array}{l}\text { Net } \\
\text { return }\end{array}$ & & \\
\hline Palmarosa & $\begin{array}{c}₹ \\
40,000\end{array}$ & $\begin{array}{c}₹ \\
1,20,000\end{array}$ & $\begin{array}{c}125-150 \\
\text { kg oil }\end{array}$ & $\begin{array}{c}\text { ₹ } 1400- \\
1500 \mathrm{~kg}^{-1} \text { oil }\end{array}$ \\
\hline Khus & $\begin{array}{c}₹ \\
75,000\end{array}$ & $\begin{array}{c}₹ \\
1,25,000\end{array}$ & $\begin{array}{c}20-25 \text { kg } \\
\text { oil }\end{array}$ & $\begin{array}{c}\text { ₹ } 12,000- \\
15,000 k^{-1} \\
\text { oil }\end{array}$ \\
\hline Rosemary & $\begin{array}{c}₹ \\
60,000\end{array}$ & $\begin{array}{c}₹ \\
1,80,000\end{array}$ & $\begin{array}{l}\text { 125-150 } \\
\text { kg oil }\end{array}$ & $\begin{array}{c}\text { ₹ 2000-3000 } \\
\mathrm{kg}^{-1} \text { oil }\end{array}$ \\
\hline $\begin{array}{l}\text { Cham- } \\
\text { momile } \\
\text { (Guleba- } \\
\text { buna) }\end{array}$ & $\begin{array}{c}₹ \\
50,000\end{array}$ & $\begin{array}{c}₹ \\
1,50,000\end{array}$ & $\begin{array}{c}5000-7000 \\
\mathrm{~kg} \text { (fresh } \\
\text { flower), } \\
\text { and } 4-5 \mathrm{~kg} \\
\text { oil }\end{array}$ & $\begin{array}{c}\text { ₹ } 200 \mathrm{~kg}^{-1} \\
\text { dried flower, } \\
\text { ₹ } 30,000- \\
40,000 \mathrm{~kg}^{-1} \\
\text { oil }\end{array}$ \\
\hline
\end{tabular}

Source: (Hand book of medicinal and aromatic plants cultivation, Central Institute of medicinal and aromatic plants),

\section{Conclusion}

Establishing entrepreneurship in this sector has wide scope. Medicinal and aromatic plants are demanded by large number of industries in huge quantities for manufacturing of herbal and cosmetic products. So, marketing, supply chain, consultancy, processing and trading is main way of entrepreneurship in medicinal and aromatic plants. Institutional and government support also plays an important role in creating awareness, providing training, subsidies for cultivation, marketing, processing and establishment of entrepreneurship in medicinal and aromatic plants.

\section{References}

Aush Gyanya, 2016. Hand book of medicinal and aromatic plants cultivation, Central Institute of medicinal and aromatic plants, CIMAP, Lucknow.

Assocham Report, 2008. Future of herbal exports conducted by the associated chambers of commerce and industry of India.

Barwal, V.S., Garg, V., Sharma, R., 2010. Development and quality evaluation of aonla mouth freshener, Journal of food science and technology 47, 697-699.

Chaubey, V., 2011. Market system of Indian medicinal plants, problem and possibilities, Economic affairs 56, 75-79.

Gudapaty, P., Indavarapu, S., Korwar, G.R., Shankar, A.K., Adake, R.K.V, Bandi, V., Kanchu, S.R., 2010. Effect of open air drying, LPG, based and pre-treatments on the quality of Indian gooseberry (aonla), Journal of food science and technology 47, 541-548.

Karkala, M., Bidya, B., 2013. Aloe vera a wonder plant its history, cultivation and medicinal uses. Journal of Pharmacognosy and Phytochemistry 2, 85-88.

Kapoor, R.T., 2012. Indigenous utilization and potential of medicinal plants in the Phulpur tehsil of Allahabad district India. Research Journal of Medicinal Plants 6, 225-235.

Mishra, D., Singh, R.K., 2013. Agribusiness and entrepreneurship development through medicinal and aromatic plant and Indian state of affairs, International journal of food, agriculture and veterinary science 3, 238-246.

Priyanka, 2014. Evaluation of commercial amla product thesis, Department of food science and nutrition, university of Agriculture GKVK, Bangalore.

Qureshi, A., Jadhav, Gupta, S., 2011. In vitro clonal propagation of Cassia tora L.: a medicinal plant. Biotechnology 10, 546-550.

Rao, R., 2012. Scope and potential of medicinal and aromatic plants products for small and medium enterprises Journal of pharmacognosy 3, 112-114.

Srivastava, H.C., 2014. Medicinal and aromatic plants, Rameshwar singh, ICAR, New Delhi, 1-181. 